\title{
Mobile Application for Training of Foreign Students with Gamification Techniques and Speech Recognition Technology
}

\author{
Nisaul Barokati Seliro Wangi ${ }^{1}$, Madekhan ${ }^{2}$ \\ ${ }^{1}$ Universitas Islam Darul Ulum Lamongan \\ 2Universitas Islam Lamongan \\ nisa@unisda.ac.id, madekhan@unisla.ac.id
}

\begin{abstract}
:
The purpose of this research is to produce a mobile learning product that uses gamification techniques and valid speech recognition technology as a source of learning and is effective for training the pronunciation of foreign students. This type of research is a development research that uses the Lee \& Owens model and is validated by 1 media expert, 1 material expert and 1 gamification learning design expert. The results of this study indicate that this application is valid and can be used for learning, students successfully complete the material, practice questions and reach the specified learning standards.
\end{abstract}

Keyword: Mobile Aplication, Gamification, Speech Recognition

\section{INTRODUCTION}

The BIPA course and training program at Universitas Islam Darul 'ulum Lamongan intended for foreign students has the aim to master the four aspects of language skills which include listening, reading, speaking and writing skills. These four skills should be mastered well so that in the process of learning Indonesian, the material can be conveyed and run smoothly. In the classroom, BIPA students experienced many obstacles including (1) Students felt that the hours of meeting to learn Indonesian were still lacking; (2) The students' speaking skills are still lacking or not yet skilled in expressing opinions or still embarrassed to speak; (3) students still use a lot of language from their own country, and (4) in terms of writing, students still have difficulty understanding spelling and stringing words into sentences.

The BIPA lecturer has dealt with the problem by asking students to look for reading material and material on the internet using the smartphone they carry. However, this is not optimal because the materials are only in the form of e-books and the sources are not in one place or separated. In addition, the need for verbal communication by BIPA students has not been facilitated by the availability of teaching materials, especially speaking skills. For this reason, solutions are needed to facilitate learning, mastery of the material and understanding of the Indonesian vocabulary. One way to practice the speaking skills of BIPA students is to develop an android mobile application using Speech Recognition technology. Speech Recognition is the process of controlling an application using sound based on the spoken word, this can replace the keyboard 
function on a smartphone. Examples of the application of this technology are the technology "OK Google" on Android smartphones and "Siri" on Apple iOS smartphones. Speech recognition technology is very appropriate when applied to BIPA students because this technology invites users to say words and speak so that the application runs. this is good to help BIPA students to be proficient in Indonesian.

\section{LITERATURE REVIEW}

\section{Gamification}

According to Kapp, Setiana \& Hansun Gamification is a process that aims to change the non-game context (eg: marketing) to be more interesting by integrating game elements (game thinking, game design and game mechanics). The use of gamification is very effective in creating activities that are usually boring, unpleasant, or less challenging to be more fun to do (Kapp, 2013; Setiana \& Hansun, 2017)

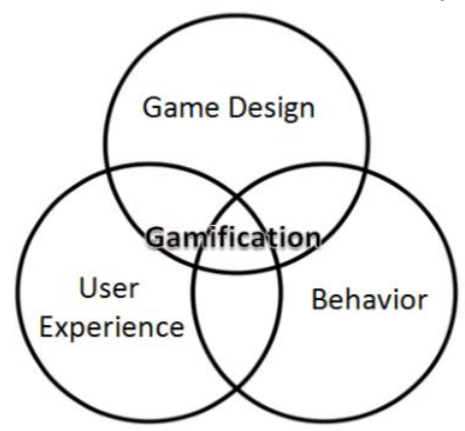

Figure 1. The concept of gamification according to Setiana \& Hansun

At first gamification was widely used for world marketing, gamification is now widely applied in the world of education. Gamification learning methods that emphasize learning, with the aim to foster motivation to learn and change student understanding. Research conducted by Sakai \& Shiota (2016), Gressick \& Langston (2017) and Selirowangi (2018) related to the use of gamification in the classroom to improve learning and learning to produce positive and significant results.

\section{Mobile Applications use Speech Recognition Technology}

Speech Recognition is the process of identifying sounds based on the spoken word by converting an acoustic signal, which is captured by an audio device. Speech Recognition is also a system used to recognize word commands from human voices and then translate them into data that is understood by computers. At this time, this system is used to replace the input role of the keyboard and mouse.

The advantage of this system is the speed and ease of use. Words that are captured and recognized can be the final result, for an application such as command \& control, data input, and document preparation. The parameter being compared is the level of sound suppression which will then be matched with the available database templates. While the speech recognition system based on the person speaking is called speaker 
recognition. Research related to application development that utilizes speech recognition shows valid results and can be used well by users (Dewanta, Isnanto, \& Martono, 2015; Ericksoon \& Kuswardayan, 2016; Rahmantara, Wardhani, \& Saf, 2018).

\section{METHOD}

The development model used uses the model proposed by Lee \& Owens. The reason for choosing this model is because this model is a model that is devoted to developing learning media (mobile learning) to be applied on a small scale or still in the form of a prototype that will be continuously evaluated and improved (Lee \& Owens, 2004).

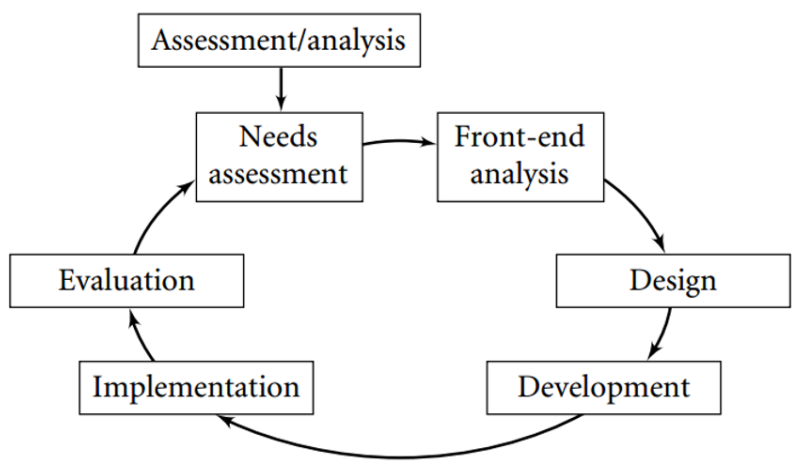

Figure 2. Lee \& Owens development model (Lee \& Owens, 2004)

Mobile application development steps:

1. Analyze the needs of BIPA students by conducting interviews with BIPA students and BIPA Lecturers.

2. Design the storyboard display of the mobile application.

3. Develop a prototype of a mobile application by adding gamification techniques and speech recognition technology.

4. After the prototype development is complete, it is continued with trials to media experts, material experts, gamification experts and small group and field trials to BIPA students.
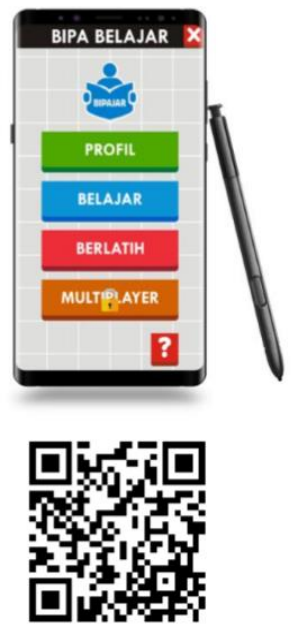

Figure 3. Prototype of Mobile Application 
The trial development of this mobile application involves testing of media experts, material experts and gamification learning design experts, each of which is carried out by 1 person who is competent in his field. While the small group trial was conducted on 3 BIPA students at Darul Islamic University 'ulum Lamongan and field trials were conducted by 18 BIPA students at Universitas Islam Darul 'ulum Lamongan.

The assessment questionnaire uses a scale of 1-5 numbers with the provision that a value of 1 means that it is not very good/very inappropriate or very inappropriate, value 2 means that it is not good/not quite right/not appropriate, value 3 means good enough/quite right/quite appropriate, a 4 value is good/right/appropriate, and a value of 5 means very good/very appropriate/very appropriate. To process the percentage data from experts and instructors in expert tests and field trials, the following formula is used to find the feasibility of teaching materials.

$$
P=\frac{\sum X}{\sum X_{i}} \times 100 \%
$$

Explanation:

$P \quad=$ precentage

$\sum X=$ total respondents in an item

$\sum X_{i}=$ total ideal answer in an item

$100=$ constant

After a percentage is collected from the overall data processing, it is included in the product eligibility criteria which were also adapted from (Arikunto, 2009). Explanation of product eligibility criteria is explained in the following table.

Table 1. Product Eligibility Criteria

\begin{tabular}{|c|c|c|}
\hline Precentage & Qualification & Follow-up \\
\hline $85 \%-100 \%$ & Very Decent & Implementation \\
\hline $75 \%-84 \%$ & Worthy & Implementation \\
\hline $56 \%-74 \%$ & Decent enough & Revision \\
\hline$<55 \%$ & Inadequate & Revision \\
\hline
\end{tabular}

\section{RESULTS AND DISCUSSION \\ Results}

Based on trials that have been carried out to one media expert, one material expert, one design expert on gamif ikas i defense and field trials, the following data are obtained:

Table 2. Table of Results of Media Expert Validation

\begin{tabular}{|c|l|c|}
\hline No & \multicolumn{1}{|c|}{ Description } & Value \\
\hline \multicolumn{1}{|c|}{ Aspects of the appearance of the application } & 4 \\
\hline 1 & Display Login and Registration Pages & 5 \\
\hline 2 & Display Help Page & 4 \\
\hline 3 & Display Main Page Page & 4 \\
\hline
\end{tabular}




\begin{tabular}{|c|l|c|}
\hline No & \multicolumn{1}{|c|}{ Description } & Value \\
\hline 4 & Profile Page Views & 4 \\
\hline 5 & Material Page Views & 4 \\
\hline 6 & Practical Page Views & 4 \\
\hline 7 & Multiplayer Page Views & 4 \\
\hline 8 & Color Selection, Type and Font Size & 5 \\
\hline 9 & Layout of buttons, images, icons and other visual elements & 5 \\
\hline 10 & $\begin{array}{l}\text { The use of language that is easy to understand, good, correct } \\
\text { and effective }\end{array}$ & 5 \\
\hline Aspects of Application Functions & 5 \\
\hline 11 & Icons and buttons function properly & 4 \\
\hline 12 & The application loading process is fast & 5 \\
\hline 13 & Ease of operation of the application & 5 \\
\hline 14 & Applications can run on all types of android & 5 \\
\hline 15 & The application does not hang or crash when running & 5 \\
\hline 16 & Speech recognition function can work well & 5 \\
\hline 17 & Multiplayer function (online) can work well & 4 \\
\hline 18 & Login and register functions work well & 5 \\
\hline 19 & Application size & \\
\hline 20 & Clarity of use instructions & \\
\hline
\end{tabular}

Table 3. Table of Results of Material Expert Validation

\begin{tabular}{|c|c|c|}
\hline No & Description & Value \\
\hline \multicolumn{3}{|c|}{ Application Display Aspects } \\
\hline 1 & Color Selection, Type and Font Size & 5 \\
\hline 2 & Layout of buttons, images, icons and other visual elements & 5 \\
\hline 3 & Attractive and proportional application display & 4 \\
\hline 4 & Ease of operation of the application & 5 \\
\hline 5 & Clarity of the functions of each button & 4 \\
\hline \multicolumn{3}{|c|}{ Material Substance Aspects } \\
\hline 6 & The truth of the contents of the material presented & 5 \\
\hline 7 & $\begin{array}{l}\text { The use of language that is easy to understand, good, correct } \\
\text { and effective }\end{array}$ & 4 \\
\hline 8 & The appearance of material rashes & 5 \\
\hline 9 & Depth and accuracy of the material & 4 \\
\hline 10 & $\begin{array}{l}\text { The material is structured to help students practice } \\
\text { pronunciation }\end{array}$ & 5 \\
\hline \multicolumn{3}{|c|}{ Learning Aspects of BIPA } \\
\hline 11 & Application supports BIPA learning & 4 \\
\hline 12 & $\begin{array}{l}\text { Able to support the independence of learning of BIPA } \\
\text { students }\end{array}$ & 4 \\
\hline 13 & Application is made according to BIPA teaching materials & 5 \\
\hline 14 & $\begin{array}{l}\text { The application can be used as a learning media for BIPA } \\
\text { students }\end{array}$ & 5 \\
\hline 15 & $\begin{array}{l}\text { The application is able to motivate and attract the attention of } \\
\text { BIPA students }\end{array}$ & 4 \\
\hline
\end{tabular}

Table 4. Table of Results of Expert Validation Design Gamification Learning 


\begin{tabular}{|c|l|c|}
\hline No & \multicolumn{1}{|c|}{ Description } & Value \\
\hline Aspects of Application Functions & 5 \\
\hline 1 & Icons and buttons function properly & 5 \\
\hline 2 & The application loading process is fast & 5 \\
\hline 3 & Ease of operation of the application & 5 \\
\hline 4 & Applications can run on all types of android & 5 \\
\hline 5 & The application does not hang or crash when running & 5 \\
\hline 6 & Speech recognition function can work well & 5 \\
\hline 7 & Multiplayer function (online) can work well & 5 \\
\hline 8 & Login and register functions work well & 5 \\
\hline 9 & Application size & 5 \\
\hline 10 & Clarity of use instructions & \\
\hline Gamification Aspects & 5 \\
\hline 11 & Gamification design is in accordance with BIPA learning & 4 \\
\hline 12 & (pronunciation) & 5 \\
\hline 13 & Gamification rules are clear & 5 \\
\hline 14 & Gamification challenge is clear & 4 \\
\hline 15 & Prize (reward / archievement) gamification is clear & 5 \\
\hline 16 & Gamification feedback is appropriate & 5 \\
\hline 17 & Learning progress (progress player) gamification is & 5 \\
\hline 18 & appropriate & 5 \\
\hline 19 & Gamification leaderboard is appropriate & 5 \\
\hline 20 & Social engagement (multiplayer) gamification is appropriate & 5 \\
\hline Learning Aspects & 5 \\
\hline 21 & This application fits the learning objectives & \\
\hline 22 & This application helps student learning & 5 \\
\hline 23 & According to student needs & 5 \\
\hline 24 & Able to motivate and attract the attention of students & \\
\hline 25 & Able to support the independence of student learning & \\
\hline
\end{tabular}

Table 5. Results Trials

\begin{tabular}{|c|c|c|c|c|c|c|c|c|c|c|}
\hline & \multicolumn{10}{|c|}{ Item Value } \\
\hline Sample & $\mathbf{1}$ & $\mathbf{2}$ & $\mathbf{3}$ & $\mathbf{4}$ & $\mathbf{5}$ & $\mathbf{6}$ & $\mathbf{7}$ & $\mathbf{8}$ & $\mathbf{9}$ & $\mathbf{1 0}$ \\
\hline $\mathbf{X 1}$ & 5 & 5 & 4 & 5 & 5 & 5 & 5 & 3 & 5 & 5 \\
\hline $\mathbf{X 2}$ & 5 & 4 & 5 & 3 & 5 & 5 & 5 & 4 & 4 & 5 \\
\hline $\mathbf{X 3}$ & 4 & 4 & 4 & 4 & 5 & 4 & 5 & 4 & 4 & 4 \\
\hline $\mathbf{X 4}$ & 5 & 4 & 4 & 4 & 4 & 5 & 4 & 4 & 4 & 4 \\
\hline $\mathbf{X 5}$ & 4 & 4 & 4 & 5 & 5 & 4 & 4 & 4 & 4 & 4 \\
\hline $\mathbf{X 6}$ & 5 & 4 & 4 & 4 & 4 & 4 & 4 & 4 & 4 & 4 \\
\hline $\mathbf{X 7}$ & 4 & 4 & 5 & 4 & 4 & 4 & 4 & 4 & 4 & 4 \\
\hline $\mathbf{X 8}$ & 5 & 4 & 4 & 4 & 4 & 4 & 3 & 4 & 4 & 4 \\
\hline $\mathbf{X 9}$ & 4 & 4 & 4 & 4 & 4 & 5 & 4 & 4 & 4 & 3 \\
\hline $\mathbf{X 1 0}$ & 5 & 4 & 3 & 3 & 4 & 5 & 3 & 5 & 4 & 2 \\
\hline $\mathbf{X 1 1}$ & 4 & 4 & 5 & 3 & 4 & 4 & 5 & 1 & 3 & 5 \\
\hline $\mathbf{X 1 2}$ & 4 & 5 & 4 & 3 & 3 & 4 & 3 & 4 & 4 & 3 \\
\hline
\end{tabular}




\begin{tabular}{|c|c|c|c|c|c|c|c|c|c|c|}
\hline & \multicolumn{10}{|c|}{ Item Value } \\
\hline Sample & $\mathbf{1}$ & $\mathbf{2}$ & $\mathbf{3}$ & $\mathbf{4}$ & $\mathbf{5}$ & $\mathbf{6}$ & $\mathbf{7}$ & $\mathbf{8}$ & $\mathbf{9}$ & $\mathbf{1 0}$ \\
\hline X13 & 3 & 4 & 3 & 3 & 4 & 4 & 4 & 4 & 4 & 4 \\
\hline X14 & 4 & 4 & 3 & 4 & 5 & 4 & 4 & 2 & 3 & 4 \\
\hline X15 & 4 & 4 & 3 & 4 & 4 & 4 & 3 & 3 & 4 & 3 \\
\hline X16 & 3 & 3 & 2 & 4 & 4 & 5 & 3 & 4 & 4 & 4 \\
\hline X17 & 2 & 5 & 5 & 4 & 4 & 5 & 4 & 1 & 2 & 3 \\
\hline X18 & 4 & 3 & 2 & 3 & 4 & 4 & 4 & 3 & 3 & 4 \\
\hline
\end{tabular}

In the trial related to the success of the BIPA student car application was given 3 days to try the Mobile application. The minimum completeness criteria is 70 . From the results of monitoring the learning progress of 18 BIPA students in practicing pronunciation. Data obtained as follows.

Table 6. Presentation Table of BIPA Student Pronunciation Practice Progress

\begin{tabular}{|c|c|c|c|}
\hline User & 1st Day & 2nd Day & 3rd Day \\
\hline 1 & 9,76 & 35,56 & 88,89 \\
\hline 2 & 17,07 & 75,56 & 100,00 \\
\hline 3 & 9,76 & 62,22 & 80,00 \\
\hline 4 & 9,76 & 46,67 & 88,89 \\
\hline 5 & 31,71 & 57,78 & 95,56 \\
\hline 6 & 7,32 & 64,44 & 73,33 \\
\hline 7 & 31,71 & 62,22 & 91,11 \\
\hline 8 & 34,15 & 64,44 & 80,00 \\
\hline 9 & 12,20 & 57,78 & 82,22 \\
\hline 10 & 36,59 & 37,78 & 68,89 \\
\hline 11 & 41,46 & 44,44 & 73,33 \\
\hline 12 & 12,20 & 60,00 & 75,56 \\
\hline 13 & 29,27 & 46,67 & 66,67 \\
\hline 14 & 14,63 & 73,33 & 91,11 \\
\hline 15 & 12,20 & 66,67 & 88,89 \\
\hline 16 & 12,20 & 44,44 & 57,78 \\
\hline 17 & 21,95 & 66,67 & 80,00 \\
\hline 18 & 46,34 & 55,56 & 100,00 \\
\hline
\end{tabular}

\section{DISCUSSION}

Mobile Application is an application that uses gamification techniques and speech recognition technology that aims to train the pronunciation of BIPA students. From the results of the validation of media experts the value obtained $91.00 \%$ which has valid criteria and is suitable for use, the results of the validation of the material experts obtained a value of $90.67 \%$ which has valid criteria and is suitable for use and the results of the validation of the gamification learning design expert are $97.33 \%$. valid and feasible to use. 
From the results of small group trials the value of $78.00 \%$ is obtained which has valid criteria and is suitable for use, and the results of field trials are obtained value of $78.67 \%$. has valid criteria and is suitable for use.

From the results of the 3-day learning progress, the following conclusions are obtained:

1. 1st day, the average student progress is $21.68 \%$ and there are no students who have passed the minimum completeness criteria.

2. 2nd day, the average student progress was $56.79 \%$ and there were 2 students who passed the minimum completeness criteria.

3. On the 3rd day, the average student progress was $82.35 \%$ and 15 students passed the minimum completeness criteria.

\section{CONCLUSIONS AND SUGGESTIONS}

\section{Conclusions}

Utilization of a Mobile application using gamification techniques and speech recognition technology can optimize the process of delivering BIPA student material, especially in word pronunciation.

Mobile applications are one of the learning devices that can support and optimize the learning process. Because the Mobile Application has independent and interactive criteria.

The Mobile Application is declared to be very valid or feasible to be used for BIPA student learning. This is evidenced by the results of statistical calculations namely from media experts obtained a percentage score of $91.00 \%$, material experts at $90.67 \%$ and learning design experts as big as $97.33 \%$. From the small group trials obtained a percentage of $78.00 \%$, field trials of $78.67 \%$ and student learning progress of $82.35 \%$.

From the results of the validation and learning progress scores, it was concluded that the Mobile application was declared valid and was suitable for practicing BIPA student pronunciation.

\section{Suggestions}

Based on responses from media experts, material experts, learning design experts and BIPA students, the following mobile learning products can be revised in the following sections: (1) Some material is too difficult for BIPA students to pronounce so it is better to make the material easier, (2) Developing a version for iOS, (3) Adding images and animations so that they are not monotonous in appearance, and (4) Instructions for use in the English version.

\section{REFERENCES}

Arikunto, S. (2009). Dasar-dasar Evaluasi Pendidikan (edisi revisi).

Dewanta, A., Isnanto, R. R., \& Martono, K. T. (2015). Perancangan Aplikasi Permainan Let's Say dengan Interaksi Pengenalan Ucapan. Jurnal Teknologi Dan Sistem Komputer, 3(1), 72-78. 
Ericksoon, H. A., \& Kuswardayan, I. (2016). Rancang Bangun Game Berhitung Spaceship Dengan Pengendali Suara Menggunakan Speech Recognition Plugin. Jurnal Teknik ITS, 5(2), A620-A624.

Gressick, J., \& Langston, J. B. (2017). The guilded classroom: using gamification to engage and motivate undergraduates. Journal of the Scholarship of Teaching and Learning, 17(3), 109-123.

Kapp, K. M. (2013). The gamification of learning and instruction fieldbook: Ideas into practice. John Wiley \& Sons.

Lee, W. W., \& Owens, D. L. (2004). Multimedia-based instructional design: computerbased training, web-based training, distance broadcast training, performance-based solutions. John Wiley \& Sons.

Rahmantara, D. S., Wardhani, K. D. K., \& Saf, M. R. A. (2018). Aplikasi Pengenalan Nama Surah pada Juz ke 30 Kitab Suci Al-Qur'an Menggunakan Speech Recognition. Jurnal RESTI (Rekayasa Sistem Dan Teknologi Informasi), 2(1), 345-353.

Sakai, K., \& Shiota, S. (2016). A Practical Study of Mathematics Education Using Gamification. International Association for Development of the Information Society.

Selirowangi, N. B. (2019). Pengaruh gamifikasi dan motivasi berprestasi terhadap hasil belajar mahasiswa. SKRIPSI Mahasiswa UM.

Setiana, H., \& Hansun, S. (2017). Gamified Android Based Academic Information System. International Journal of Evaluation and Research in Education, 6(2), 164-173. 